\title{
Are State-Owned Companies Underperforming? A Case Study of Chinese Listed Property Companies
}

\author{
Qiulin $\mathrm{Ke}^{*}$
}

\begin{abstract}
China's privatization program was initiated in April 1984 through the State Commission; however, the State continues to hold dominant shares in privatized companies. The fast growing economy has created a favorable environment for the private economy to develop, especially in property markets that have been booming since 2000. This study uses data of all the listed property companies in China's stock markets from 2000 to 2005 to investigate two issues: (1) who owns China's listed property companies; and (2) the performance differences between these two types of property companies. The goals of the research are to examine whether state-owned companies are less efficient and underperform privately-owned companies in the property sector and what type of property companies are good investments.
\end{abstract}

The further reform of housing privatization in China triggered rapid expansion of the property market in the second half of 2000 and the expansion, fueled by continuous economic growth and massive urbanization, has continued ever since. From 2000 to 2005 , investment in fixed assets increased $20 \%$ p.a. and real estate investment increased $25 \%$ p.a., representing $17 \%$ of total fixed asset investment (Exhibit 1). Residential property investment accounted for $68 \%$ of total real estate investment, office buildings, $4.7 \%$, and retail, industrial, and others, $27.3 \%$. The real estate sector in China is viewed as the housing economy, with residential investment and development being in a predominant position.

However, foreign direct investment (excluding Hong Kong) in China's real estate market takes on a less important position, representing less than $5 \%$ of total real estate investment, largely due to the volatility of governmental policy regarding foreign direct investment in real estate, the complexity of practical operation, and the daunting regulatory regime. In 2005, foreign direct investment in China's real estate market was USD 5.4 billion, less than $3 \%$ of total real estate investment. This figure surged to USD 8.2 billion in 2006, with foreign investors purchasing completed development projects in major and the second-tier cities (JLL, 2007a). For example, as testimony to the growing international confidence in Chinese property during 2006, Pramerica purchased a $50 \%$ interest in the Walk Shopping Centre in Shenzhen for USD 118 million, and Standard Chartered made its first investment in the Chinese real estate market by placing USD 50 million in the Shanghai-based Shimao Property Holdings (JLL, 2007b).

\footnotetext{
*Nottingham Trent University, Nottingham, NG1 4BU, UK or qiulin.ke@ntu.ac.uk.
} 
Exhibit 1

Investment Profile in China (2000-2005)

\begin{tabular}{lccccccc}
\hline Value in USD Billions & 2000 & 2001 & 2002 & 2003 & 2004 & 2005 & Average \\
\hline Fixed asset investment & 397.6 & 445.6 & 525.4 & 665.7 & 846.3 & $1,070.1$ & \\
Growth rate (\%) & $11 \%$ & $12 \%$ & $18 \%$ & $27 \%$ & $27 \%$ & $26 \%$ & $20 \%$ \\
Real estate investment & 59.2 & 75.4 & 93.5 & 122.1 & 158.9 & 190.3 & \\
Growth rate (\%) & $20 \%$ & $27 \%$ & $24 \%$ & $31 \%$ & $30 \%$ & $20 \%$ & $25 \%$ \\
\% of total fixed asset investment & $15 \%$ & $17 \%$ & $18 \%$ & $18 \%$ & $19 \%$ & $18 \%$ & $17 \%$ \\
Foreign direct investment & 4.66 & 5.14 & 5.66 & 5.24 & 5.95 & 5.42 & \\
Growth rate (\%) & & $10 \%$ & $10 \%$ & $-7 \%$ & $14 \%$ & $-9 \%$ & $4 \%$ \\
\% of real estate investment & $7.9 \%$ & $6.8 \%$ & $6.1 \%$ & $4.3 \%$ & $3.7 \%$ & $2.8 \%$ & $5 \%$ \\
\hline
\end{tabular}

Notes: The source is www.stats.gov.cn.

Nevertheless, foreign direct investment currently plays an insignificant role in China's booming real estate market. The Chinese government exerts policy restrictions on foreign property investment. According to a report by Jones Lang LaSalle (2007a), the restrictions include such items as that for total investment of more than USD 10 million, the registered capital of a real estate foreign investment enterprise should not be lower than $50 \%$ of the total investment (previously $40 \%$ ), and if the registered capital of a foreign investment enterprise is less than $35 \%$ of the total investment, loans are not allowed to be taken out, etc.

Investing in listed property companies to reap the benefit of the booming Chinese property market is one of the routes for foreign investors to enter the Chinese property market. However, one of the barriers in investing in China's stock markets is the share structure segmentation. Contrary to the former Soviet Union and other Eastern European countries who took a "Big Bang" approach (Lipton and Sachs, 1990), privatizing all firms at once, the Chinese government has taken a gradual approach, advocating economic stabilization, liberalization, and privatization as the necessary components of economic reform. The government privatized its state-owned enterprises (SOE) by retaining a control right in many of the newly privatized companies, especially the ones in key industries. Accordingly, the share structure is split into tradable and non-tradable shares. Tradable shares (A-shares and B-shares) ${ }^{1}$ are the conventional shares that can be freely traded in the stock markets, while nontradable shares are further classified as state shares and legal person shares. State shares are owned directly by the government department, its agent, or the listed company itself on behalf of the state. Legal person shares are owned by an institution that has a legal person status, be it a SOE or a privately-owned enterprise (POE). The transfer of state shares and legal person shares is restricted and needs the approval of China's Securities Regulatory Commission (CSRC); normally, the transfer price is negotiated under the counter between two parties.

There has been a wide debate on the drawbacks of this split share structure in China's stock market. The key issues include the protection of investor's interests and rights, 
along with the corporate governance related to the ownership structure. State shares have been argued to have an inverse impact on firm performance (Wang and Xu, 1997; Chen, Lee, and Rui, 2001; Wei and Verela, 2003; and Bai, Liu, Lu, Frank, and Zhang, 2004). The split share structure has been believed to restrain the further growth of China's stock market and should be reformed. As a result, the Chinese government implemented the split share structure reform in September 2005 to let all the shares float in the stock markets step-by-step. The aims of the reform are to protect investor interests, enhance corporate governance, and encourage institutional investment in the Chinese stock markets. The reform opened up opportunities for foreign investors to invest in China's stock market.

Exhibit 2 demonstrates the share structure profile of China's stock markets in 2005. The majority of China's listed companies have a mixed ownership structure, with the state retaining a controlling number of shares. In 2005, nearly $60 \%$ of shares (including lock-up sales shares ${ }^{2}$ ) are non-tradable state shares and legal person shares; among those, $10.58 \%$ are lock-up sales shares, which are not allowed to be sold publicly within 12 months from the time the company announced the split share reform implementation plan. State shares account for $28 \%$ of total shares and legal person shares are $21 \%$. The number of tradable shares will increase after the unlocking of these state shares in the following years; meanwhile, the proportion of state shares will decline. The state may retreat from the controlling position in some of the companies, but are likely to retain control over some of the large companies.

The property sector is more liquid than the whole stock market (Exhibit 3). For example, in $2005,48 \%$ of property equity was tradable shares, $31 \%$ were owned directly by the state or its agent in the form of state shares and state legal person shares, and $21 \%$ were owned by private institutions (including those from Hong Kong) in the form of legal person shares. The number of shares owned by the state and/or its agent tended to decline over the study period. In 2000, the state owned $41 \%$ of property shares, which declined to $31 \%$ in 2005 . It is expected to decline further when all the shares, especially the state shares (including state-owned legal person shares), can be freely traded. The number of tradable shares rose from $39 \%$ in 2000 to $48 \%$ in 2005 , while the legal person shares remained stable at $21 \%$, on average.

One of the characteristics of China's property sector is that there is a strong presence of POEs. In the past few decades, these POEs have been actively participating in

\section{Exhibit 2}

Share Structure of China's Stock Markets in 2005

\begin{tabular}{llllll}
\hline \multicolumn{2}{l}{ Non-tradable Shares } & & \multicolumn{2}{l}{ Tradable Shares } \\
\cline { 1 - 1 } \cline { 5 - 6 } State Shares & Legal Person Shares & & A-Shares & B-Shares and Others & Lock-up Sales Shares \\
\hline $27.9 \%$ & $21.33 \%$ & $29.91 \%$ & $9.58 \%$ & $10.58 \%$ \\
\hline
\end{tabular}

Note: The source is www.cninfo.com. 


\section{Exhibit 3}

\section{Share Structure of China's Property Companies}

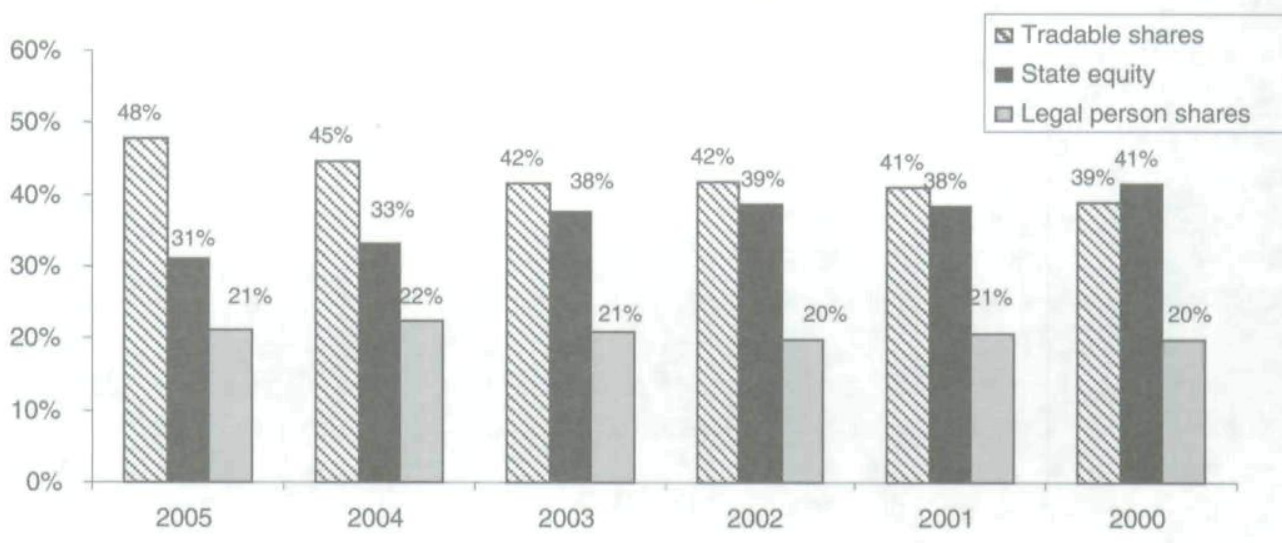

property development, and have been expanding fast and contributing greatly to China's economy and property market. In 2000, they started to seek financing in stock markets through IPOs or acquiring underperforming listed SOEs. They have formed an important component in China's property sector.

The listed property companies, particularly the SOEs, have a mixed ownership structure with tradable shares and non-tradable shares (state shares or/and state legal person shares), with the state owning the controlling number of shares in SOEs. The temporary mixed ownership is argued to be necessary (Perotti, 1994, 2003), since under uncertain public commitment, the government can credibly inspire confidence by transferring control immediately while selling ownership gradually, signaling its commitment to privatization by its willingness to bear residual risk. It is also argued that the public sector should keep control over the decision-making rights until property regulation is in place, since partial, temporary state ownership may be needed until the needed institutional and regulatory frameworks are established (Nellis, 2003).

There are quite a few researchers studying the various aspects of share issues and stock markets in China (e.g., Ma, 1995; Chui and Kwok, 1998; Sjoo and Zhang, 2000; and Chen, Lee, and Rui, 2001). Empirical studies addressing this type of ownership structure in China by differentiating state shares from legal person shares, suggest that a higher ratio of state shares leads to lower firm value (Xu and Wang, 1997; Wei and Verela, 2003; and Bai, Liu, Lu, Frank, and Zhang, 2004).

There is a wealth of literature addressing the inefficiency in SOEs ${ }^{3}$ (e.g., World Bank, 1995; and Megginson and Netter, 2001). In sum, empirical findings exhibit a significantly lower productive efficiency in comparison with POEs, leading to a lack of managerial and employee incentives to efficiency, problems of competence or corruption by state authorities, and the use of SOEs for political purposes, instead of favored constituencies. 
The purpose of this paper is first to find out who owns China's listed property companies - state agent or private institution; then, it examines whether the type of ultimate owner is relevant to firm performance by comparing the differences between the two types of companies in terms of size, profit, sustained growth, productivity, managerial incentive, operational efficiency, attracting and retaining talented individuals, and ownership concentration. There is limited research addressing the performance of China's listed property companies. Newell, Chau, Wong, and McKinnell (2005) study the direct and indirect real estate markets in China by analyzing the market performance of China's listed property companies. Ke and Isaac (2007) study the relationship between ownership concentration and business performance of Chinese listed property companies, but the productivity and efficiency and market performance issues are not considered. This paper extends the previous study by focusing on investigating the efficiency issue of Chinese listed property company in terms of ultimate owner (SOE or POE) and its impact on performance, with the aim to extend the existing knowledge of indirect investment in China's property market. In particular, this research appears to be significantly important while China is reforming the split share structure of listed companies and "foreign investors will be allowed to do some strategic mergers and acquisitions once the share reform is completed," (Shang Fulin, head of the CSRC, quoted from The Financial Times, September, 15, 2006).

The paper starts with the discussion on China's property companies, followed by a discussion of the sample, research methodology, and the empirical results. The paper closes with concluding remarks.

\section{China's Property Companies}

With the emergence and formation of China's property market in the early 1980s, China's property companies came into being as an independent entity. They were facility management divisions in SOEs, responsible for renovating and maintaining the company's buildings, including the residential buildings for the employees.

With the economic reform, production was expanded, income was increased, and people's living standard was enhanced. There was a huge demand for property. These operational departments were actively involved in property development and expanding their businesses. They took advantage of entrepreneurial real estate opportunities. In some companies, the facilities function operated as a business unit, seeking profits through real estate involvement, competing directly in the real estate market seeking development opportunities beyond the business of the parent companies-either as an independent entity or a subsidiary. The first batch of property development companies appeared in Shenzhen, Shanghai, and Guangzhou, the major costal cities in southeast China, to undertake the building and developing of Special Economic Development Zones in these cities, as promoted and supported by the central government policy.

Unlike the Hong Kong property market where the property market is highly concentrated by the largest 9 property companies, which represent $12 \%$ of the total 
market capitalization and $82 \%$ of the property company sector (Newell Chau, and Wong, 2004), China's property companies can be characterized as being large in quantity, but small in economic scale. In 2005, there were 59,242 property companies registered with the government's Industrial and Commercial Administration Department (Exhibit 4). The number of POEs and SOEs is more or less the same. The average asset held per company is only USD 0.02 billion and the revenue is USD 0.003 billion, obviously due to a lack of economic scale and competence.

In 2005, there were 51 property companies listed on Shenzhen Stock Exchange and Shanghai Stock Exchange, representing $0.1 \%$ of the total property companies. Generally speaking, the listed property companies are larger in size as measured by sales and total assets; they are more profitable, have lower gearing ratio, and outperform the property sector as a whole. Amongst them, 19 are owned by private institutions (domestic and Hong Kong); 32 are owned by the state. Obviously, the listed property sector in China is controlled by the state.

Actually, the property companies were among the ones listed earliest in China's stock markets at the beginning of 1990s. The property sector was once an influential one and property share was the barometer of entire stock markets. Now, the property sector is a small sector, being the eighth largest sector (Newell, Chau, Wong, and McKinnell, 2005) in China's stock markets. In 2005, there were 1,380 companies listed on the Shanghai Stock Exchange and the Shenzhen Stock Exchange, with market capitalization (A-shares) of USD 128.4 billion; only 51 (3.1\%) companies are in the property sector, with market capitalization (A-shares) of USD 6.6 billion, representing $5.2 \%$ of total market capitalization (Exhibit 5).

The first reason for the presence of such a small number of listed property companies in China's stock markets could be due to the government's tightening control over the new listing of a property company. The new listing of a property company via an IPO was suspended from 1995 to 2002 to cool down the overheating real estate market. The ban was lifted with the property market expansion in 2002 . From 2002 to 2005 , there were four new listings in the property sector. Another reason for the low number of listed property companies is that the threshold to the entrance of the stock markets is relatively high. The company that is seeking listing in China's stock markets must have three consecutive years of profits before they are eligible to apply for an IPO. In addition, the whole application process is complicated, time and resource consuming, and full of uncertainties; therefore, some property companies go abroad to seek going public, such as in the Hong Kong stock market.

Geographically, China's property companies can be categorized into two groups. The first group is the Special Economic Development Zone (SEDZ) group. These are the property companies whose major business activities are undertaken, largely, though not to be restricted, in Special Economic Development Zones, including utilities and infrastructure constructing, property (industrial buildings and office buildings) developing and managing, land use right transfer, and administrating the businesses settled in the SEDZ on behalf of the local government. Nine companies can be categorized into this group. The property companies in this group are SOEs, the 


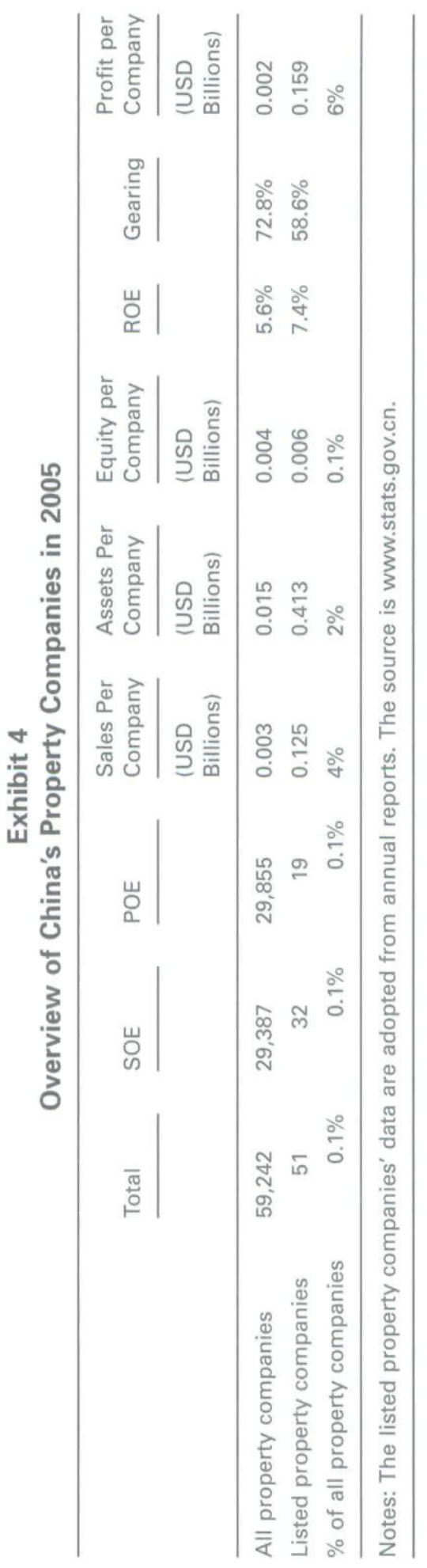




\section{Exhibit 5}

Market Capitalization (A-Shares)

\begin{tabular}{lcccccc}
\hline & 2000 & 2001 & 2002 & 2003 & 2004 & 2005 \\
\hline No. of listed companies & 1,086 & 1,160 & 1,224 & 1,287 & 1,377 & 1,380 \\
Total mrt. cap (USD billions) & 194.3 & 174.7 & 150.8 & 159.2 & 141.2 & 128.4 \\
No. of listed property companies & 34 & 49 & 49 & 53 & 53 & 51 \\
\% of total listed companies & $3.1 \%$ & $4.2 \%$ & $4.0 \%$ & $4.1 \%$ & $3.8 \%$ & $3.7 \%$ \\
Property mrt. cap (USD billions) & 8.1 & 8.0 & 8.6 & 6.9 & 7.0 & 6.6 \\
$\%$ of total Mrt. Cap & $4.2 \%$ & $4.6 \%$ & $5.7 \%$ & $4.3 \%$ & $5.0 \%$ & $5.2 \%$ \\
\hline
\end{tabular}

offshoots of local government performing the tasks of developing and managing the SEDZs. The second group is the property development and management companies, for whom developing and then trading a property is the core business. A few of them develop the property and hold it as investment to derive income; 42 companies can be categorized into this group. For the diversification of business activities, the line between two types of companies has become blurred.

Exhibit 6 shows the top five listed property companies ranked by sales; the top five are Vanke, China Merchants Shekou Holdings, Xinjiang Guanghui, Shen Changchen, and China Enterprise. Aggregately, these companies account for $36 \%$ of the sales, $43 \%$ of profit, and $23 \%$ of market capitalization in the listed property sector. Four of them are SOEs, and one, Xinjian Guanghui, is a POE. Vanke, the largest, is the only property company ranked amongst top 100 listed companies in China's stock markets. Obviously, the large property companies are controlled and owned by the state.

\section{Exhibit 6}

Top 5 Listed Property Companies Ranked by Sales (2002-2005)

\begin{tabular}{|c|c|c|c|c|c|c|}
\hline Company & Sales & Profit & Mrt. Cap. ${ }^{a}$ & Development & Rental & $\begin{array}{l}\text { FM and } \\
\text { Others }^{b}\end{array}$ \\
\hline Vanke & $3,524.2$ & 554 & $4,015.9$ & $3,440.1$ & - & 84.2 \\
\hline China Merchants Shekou Holdings & $1,325.4$ & 176.7 & 958.9 & 725.4 & 68.8 & 85.5 \\
\hline Xinjiang Guanghui & $1,138.7$ & 145.6 & 810 & 808.9 & 0.9 & - \\
\hline Shen Changchen & $1,031.6$ & 40.8 & 250.4 & 455 & 93.2 & 157.5 \\
\hline China Enterprise & $1,015.4$ & 212.5 & 783.7 & 578.5 & 21.5 & 136.5 \\
\hline Total & $8,035.3$ & $1,129.6$ & $6,818.9$ & $6,007.8$ & 184.2 & 463.4 \\
\hline$\%$ of total listed property companies & $36 \%$ & $43 \%$ & $23 \%$ & & & \\
\hline
\end{tabular}

Notes: All values are in USD millions.

a-shares.

${ }^{\mathrm{b}}$ Others include hotel management, utilities supplies, land rental, and construction engineering. 
Property development constitutes a substantial component of these property companies' activities, with rental and facilities management and others, such as hotel management, utilities supplying, and construction engineering, represented to a lesser extent. Residential property development orientation is the major characteristic of these property companies and is most evident in Vanke and Xinjiang Guanghui.

\section{Data Definition}

\section{Hypothesis}

The classic argument against state control suggests that the SOE structure is inefficient, seeks excessive employment and wages, and attracts selfish politicians, which leads to corruption and patronage and transfers the resources to its supporters (Shleifer and Vishny, 1993). The hypotheses are set up on these arguments.

Hypothesis (1): SOE is underperforming and inefficient:

$$
\begin{aligned}
\text { Performance } & =\beta_{0}+\beta_{1} \text { Sales }+\beta_{2} \text { Gearing }+\beta_{3} \text { Growth }+\beta_{4} \text { Pay } \\
& +\beta_{5} 1^{\text {st }} \text { Holder }+\beta_{6} 2^{\text {nd }} \text { Holder } \\
& +\beta_{7} \text { Others }\left(3^{\text {rd }}-10^{\text {th }} \text { Holders }\right)+\beta_{8} S O E+\varepsilon .
\end{aligned}
$$

The performance variables are the natural logarithm return on equity $(R O E)$ and share price return $(S R)$. It should be expected that $S O E$ has a negative coefficient in Equation (1).

Hypothesis (2): $S O E$ is less productive:

$$
\text { Productivity }(\log )=\beta_{0}+\beta_{1} \text { Asset/Labor }(\log )+\beta_{2} H E+\beta_{3} S O E+\varepsilon \text {. }
$$

A highly educated employee $(H E)$ would facilitate the enhanced productivity and firm performance, so it is expected this ratio has a positive impact on productivity. SOE is argued to be less productive; therefore, it is expected that SOE should be inversely related to productivity.

\section{Data Definition}

The sample selection rule used here is that each company has at least two consecutive years of financial statement data between 2000 and 2005. The two-year requirement represents an attempt to balance two sampling issues: collecting several observations for each company so that the econometric panel data technique can be used and limiting survivorship bias by allowing companies to enter and exit the panel over time. Two companies dropped out of the 2005 data set. They diverted their core business from the property sector due to the change of the controlling shareholders and the business strategy as well. There are 289 cases in the sample. 
Accounting data are obtained from the annual reports of listed property companies. Performance measures used by previous researchers to compare state ownership versus private ownership are mostly accounting-based, such as return on sales (ROS), return on total assets (ROA), and return on equity (ROE). However, the most widely used measure in the equity and performance literature is Tobin's Q. ${ }^{4}$ One difficulty with Tobin's Q is that a large proportion of shares of the listed firms in China cannot be traded freely and therefore do not have market prices. No consensus exists about how to compute the total market value of firms with a substantial percentage of nontradable shares (Bai, Liu, Lu, Frank, and Zhang, 2004). The annual stock return ${ }^{5}$ is another measure used to examine market performance. We use this ratio (SR) as a market performance indicator, in an attempt to mitigate, though not able to eliminate, the impact of non-tradable shares. The accounting performance measurement indicator used here is the natural logarithm return on equity, denoted as ROE (Ln). Productivity and operating efficiency measures like sales per employee or net income per employee are used in previous similar research. We use the sales per employee denoted as productivity to measure the productivity and the ratio of selling, general and administration costs to sales denoted as $S G \& A$ to sale to measure the operating efficiency. SOE is argued to be inefficient; therefore, this ratio is expected to be positively correlated with SOE. If employment is one of the government's objectives, SOEs should employ more workers and have lower productivity. Since most of these property companies are developers, these ratios are applicable and comparable.

The other study variables are defined as follows:

Sales $=$ The nominal operating income and the proxy of company size.

Gearing $=$ The debt-to-asset ratio. It equals the book value of the total debt divided by the book value of total assets.

Profit $=$ Calculated as the net profit.

$S O E=$ A state-owned enterprise that is used as an indicator variable. It equals one if the company is a state-owned company.

$1^{\text {st }}$ Holder $-10^{\text {th }}$ Holder $=$ Ownership structure is measured by the percentage of shares owned by the largest shareholders in the company. It is argued that ownership concentration is relevant to firm performance (Shleifer, 1998; and Megginson and Netter, 2001).

Growth $=$ Growth sustainability is measured by three-year average business growth rate to reflect the long-term growth sustainability.

Pay $=$ Manager incentive is measured by salary per senior manager. Managerial share ownership as an incentive scheme is rarely in place in China's listed companies; therefore, the senior manager's salary is used to proxy incentive scheme. The pay to manager is comprised of two parts: basic salary and performance bonus. 


\section{Labor $=$ Labor is the number of staff employed by the company. A SOE is expected to employ more staff. \\ Asset/Labor $=$ Asset utilization is measured by asset per labor. This ratio is used as proxy of efficiency and is expected to be positively related to productivity. \\ $H E=$ The potential for a company to attract and retain highly educated employees is proxied by the percentage of employees who have a higher educational background.}

\section{Descriptive Statistics Results}

The descriptive statistics are presented in Exhibit 7. SOE is significantly larger in terms of size measured by sales. The first largest shareholder is in a controlling position, holding $39 \%$ of total shares, while the first largest shareholding in a SOE is $42.9 \%$, significantly higher than the one in a POE $(31.6 \%)$. The other largest shareholders $\left(2^{\text {nd }}-10^{\text {th }}\right)$ in POEs hold a significantly larger portion of shares $(11.7 \%$ and $12.1 \%$ ) than those in SOEs $(5.7 \%$ and $7.4 \%$ ). By the end of 2005, eight SOEs had announced a split share structure reform implementation plan to float their state or state legal person shares by 2009 , representing $14.8 \%$ of total property shares. Therefore, the ratio of the first largest shareholding in SOEs is expected to decline while the number of tradable shares increases.

SOEs employ more people, pay senior manager higher, and attract more highly educated workers. Though a SOE is argued to underperform a POE and have lower productivity; however, in the property sector, SOEs have higher productivity than POEs, but the difference is insignificant. Inefficiency also exists in POEs. SOEs are more profitable in general, but POEs are growing faster. The operational efficiency variable measured by the ratio of selling, general, and administration cost to sales does not seem to suggest that a SOE is less efficient than a POE.

Who are the ultimate owners of the listed property companies? By tracing the ultimate owner along the ownership chain, we have found the government agent in the form of a holding company or an investment company, the parent company, and another $\mathrm{SOE}$, as the representative of the state, owns the state-owned listed property companies. The listed company itself, domestic companies, and Hong Kong institutions are the owners of POEs. For example, Shenzhen Construction Investment Controlling Company as representative of Shenzhen municipal government controls 4 listed property companies (Shen Wuye, 28.02\%; Shen Zhenye, 59.75\%; Shen Shenfang, $73.52 \%$; and Shen Great Wall, $34.5 \%$ ) by holding 1.2 billion state shares, accounting for $3 \%$ of total property shares in the Shenzhen stock market and the Shanghai stock market and $10 \%$ of property shares in Shenzhen stock market (Exhibit 8). Given the restructuring of the controlling shareholder in 2006, three of the companies were transferred to the Shenzhen Municipal State Assets Management and Supervision Commission, a government agent. One company (Shen Wuye) was sold to a Hong Kong investment company. Two companies announced the share reform implementation plan to float all of their state shares by the end of 2009 . 


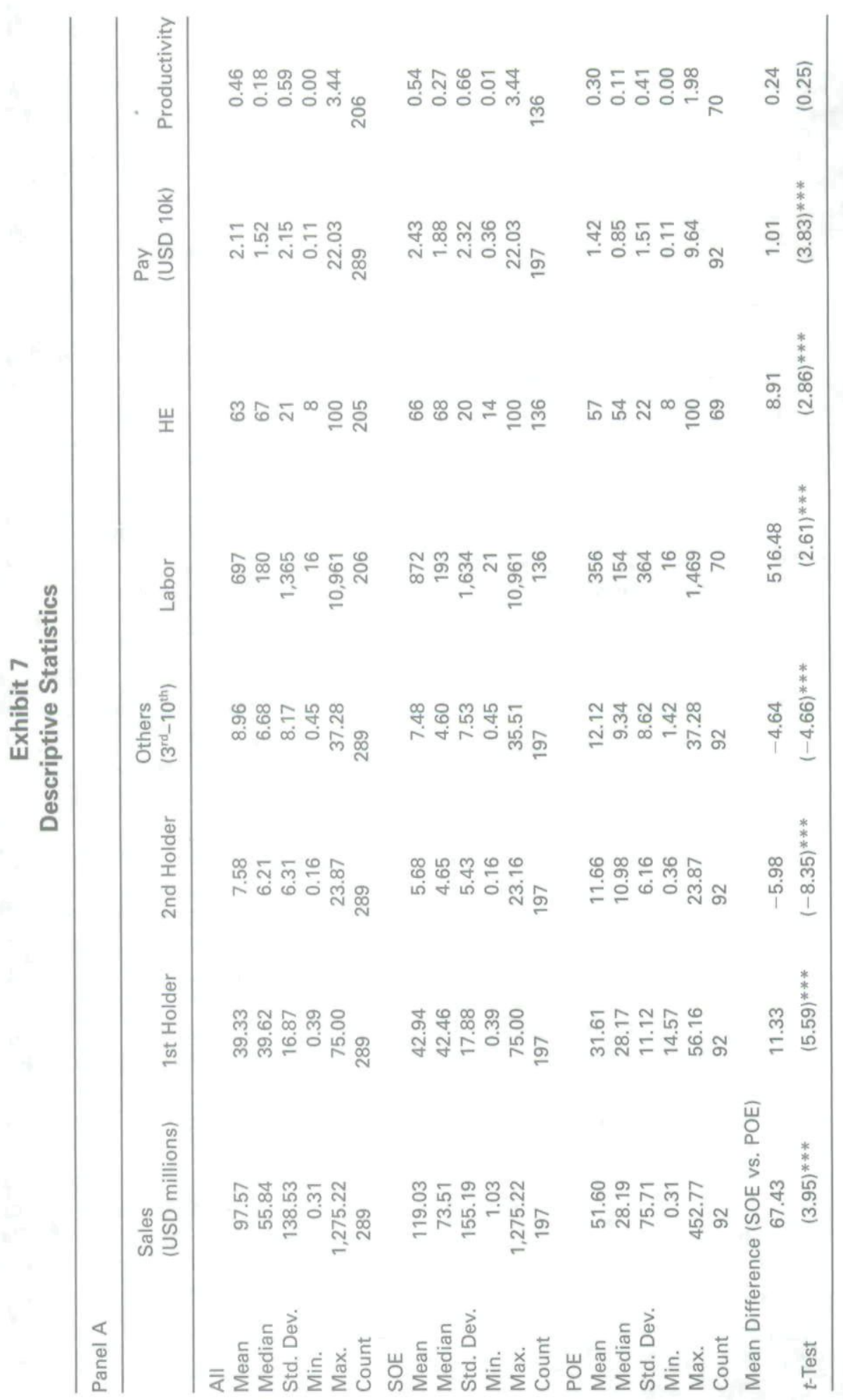

VOLUME 16, NUMBER 2, 2008 


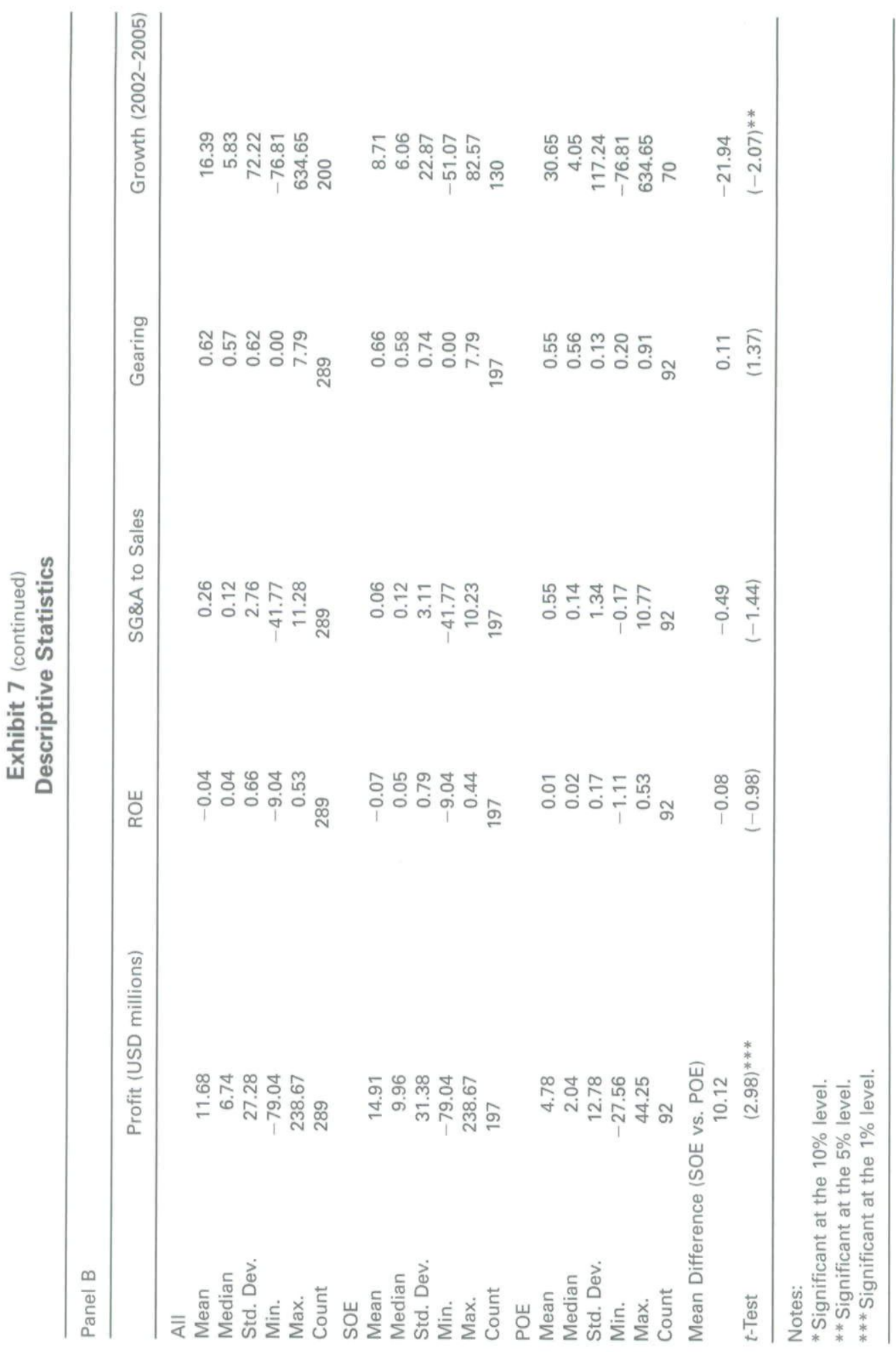




\section{The Holding Company}

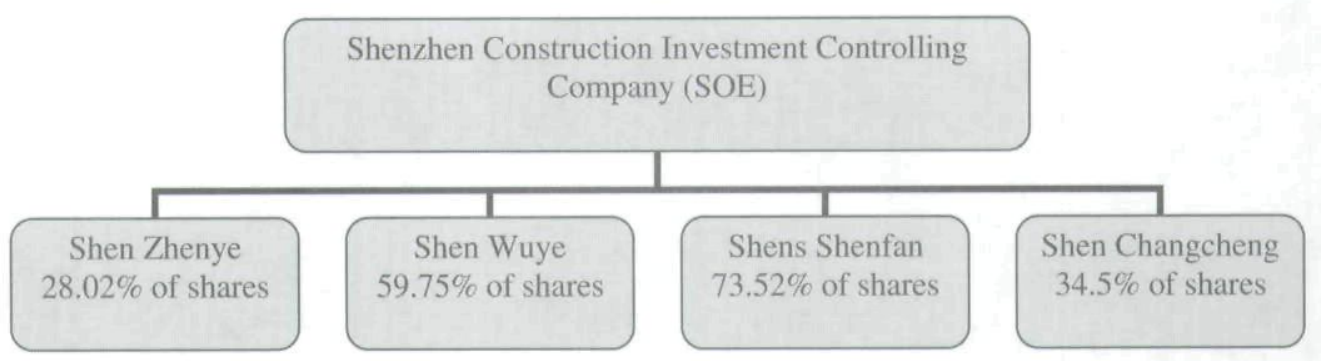

An ownership concentration structure is widely adopted by countries with poor shareholder protection. While the largest shareholder can sometimes be the state, more often it is a family, usually the founder of the firm or his descendants (La Porta, Lopez-de-Silanes, and Shleifer, 1999). This is the case for the Chinese listed property sector. However, Hart (1995) argues that there are two disadvantages to holding a large portion of shares in a company. The first is that owning a large number of shares will offset the gains from going public; the risk reduction benefits from portfolio diversification are lost. The second is that, even though large shareholdings can mitigate the agency problems, they cannot eliminate them.

\section{Results and Discussion}

The regression results are reported in Exhibit 9. The first hypothesis is rejected. The positive coefficient of SOE in the first equation indicates that SOEs perform significantly well in China's property market. Obviously, the classic argument against SOEs is not entirely applicable to China's property sector. China's property market is a highly competitive, but not a fully transparent market with the typical features of an emerging market. Politics still plays an important role in the property market and influences firm performance. The SOEs undertake the task of urban regeneration and housing development on behalf of the government and enjoy preferential treatment, which may not be available to POEs. As pointed out by one referee, SOEs can usually obtain land at lower prices (than tender or auction) by negotiating with the government, especially when the government is the controlling shareholder of the property companies. SOEs also have easier access to financial instruments provided by the state-owned banks in China. The interest rates charged by these banks were set by the state at a very low level during the period of observation and the lower rates are less accessible to POEs. SOEs are larger in size. Economic scale is important for a property company; it represents capability and competence in obtaining projects, especially large and complex projects, along with financing. Additionally, SOEs offer their employees higher job security and better salaries, therefore, attracting more highly educated people. All of these can explain the outperformance achieved by SOEs.

Firm performance is significantly related to the ownership concentration measured by the percentage of shares owned by the largest shareholders, which indicates that

VOLUME 16, NUMBER 2, 2008 
Exhibit 9

Regression Results

\begin{tabular}{|c|c|c|c|c|c|c|c|c|}
\hline & Sales & $\begin{array}{l}\text { Gearing } \\
\text { Ratio }\end{array}$ & Growth & $\begin{array}{l}\text { 1st } \\
\text { Holder }\end{array}$ & $\begin{array}{l}\text { 2nd } \\
\text { Holder }\end{array}$ & $\begin{array}{l}\text { Others } \\
\left(3^{\text {rd }}-10^{\text {th }}\right)\end{array}$ & SOE & $\begin{array}{l}\text { MAGPAY } \\
(\$ 10 k)\end{array}$ \\
\hline & 0.23 & 0.09 & 0.33 & 0.23 & 0.14 & 0.16 & 0.22 & 0.15 \\
\hline & $(2.63)^{* * *}$ & (1.18) & $(4.84)^{* * *}$ & $(2.55)^{* * *}$ & $(1.65)^{*}$ & $(1.68)^{*}$ & $(2.85)^{* * *}$ & $(1.64)^{*}$ \\
\hline$R^{2}$ & & 0.30 & & & & & & \\
\hline$F$ & & 8.68 & & & & & & \\
\hline$P$-value & & 0.00 & & & & & & \\
\hline
\end{tabular}

Panel B: Dependent Variable $=S R$

\begin{tabular}{lcccccccc}
\hline & Sales & $\begin{array}{l}\text { Gearing } \\
\text { Ratio }\end{array}$ & Growth & $\begin{array}{l}\text { 1st } \\
\text { Holder }\end{array}$ & $\begin{array}{l}\text { 2nd } \\
\text { Holder }\end{array}$ & $\begin{array}{l}\text { Others } \\
\left(3^{\text {rd }}-10^{\text {th }}\right)\end{array}$ & SOE & $\begin{array}{l}\text { MAGPAY } \\
(\$ 10 k)\end{array}$ \\
\hline & -0.15 & -0.13 & 0.12 & -0.03 & 0.15 & -0.07 & 0.09 & 0.36 \\
$R^{2}$ & $(-1.70)^{*}$ & $(-1.71)^{*}$ & $(1.71)^{*}$ & $(-0.37)$ & $(1.73)^{*}$ & $(-0.76)$ & $(1.17)$ & $(3.98)^{* * *}$ \\
$F$ & 0.12 & & & & & & & \\
$P$-value & 4.48 & & & & & & & \\
\hline
\end{tabular}

Panel C: Dependent Variable: Productivity (Log)

\begin{tabular}{|c|c|c|c|}
\hline & SOE & $\begin{array}{l}\text { Asset/labor } \\
\text { (Log) }\end{array}$ & HE (\%) \\
\hline & -0.01 & 0.52 & 0.15 \\
\hline & $(-0.23)$ & $(6.71)^{* * *}$ & $(1.89)^{*}$ \\
\hline$R^{2}$ & & 0.38 & \\
\hline$F$ & & 35.62 & \\
\hline$P$-value & & 0.00 & \\
\hline \multicolumn{4}{|c|}{$\begin{array}{l}\text { Notes: } \\
\text { * Significant at the } 10 \% \text { level. } \\
\text { ** Significant at the } 5 \% \text { level. } \\
\text { *** Significant at the } 1 \% \text { level. }\end{array}$} \\
\hline
\end{tabular}

ownership is relevant and that ownership concentration impacts performance, be it in an SOE or in a POE. Large shareholders provide at least a partial solution to the freerider problem of small investors (Shleifer and Vishny, 1986; and Shleifer, 1998) and in the countries with poor investor protection, control should be concentrated to prevent someone seizing it without fully paying for it (La Porta, Lopez-de-Silanes, and Shleifer, 1999; and Bebchuk, 1999). The coefficient of the other largest shareholders $\left(2^{\text {nd }}-10^{\text {th }}\right)$ indicates that the increase in other large shareholding is beneficial to firm performance, since these large shareholders have the incentive to 
monitor company management. These findings are consistent with other empirical studies (e.g., Wang and Xu, 1997; and Bai, Liu, Lu, Frank, and Zhang, 2004).

Firm performance is significantly related to sales, growth rate, and senior manager's salary. When the market performance measure $(S R)$ replaces $R O E$, the accounting ratio in the second regression in Exhibit 9, among the eight control variables, the sales and gearing ratio are negatively correlated with stock return $(S R)$. It seems that smaller firms have better market performance, indicating the speculative feature of the Chinese stock market, that is, the smaller firm's share prices are more likely to be manipulated by market speculators, especially given the fact that there are a smaller portion of tradable shares floating in the stock markets. Actually, the property shares experienced dramatic fall over the study period, regardless of the property market expansion. The negative relation of gearing to market performance indicates that the higher risk related to borrowing will inversely affect market performance. Growth rate and manager's salary have significantly positive effects on market performance. SOE has positive, but insignificant correlation with market performance, indicating the confidence of the investors on the SOEs to a certain extent. Among the ownership concentration variables, the $2^{\text {nd }}$ largest shareholding has a significantly positive effect on performance, consistent with the one in the first equation, but the $1^{\text {st }}$ and other $\left(3^{\text {rd }}-10^{\text {th }}\right)$ largest shareholdings have no explanatory power to the market performance.

Regarding productivity, classic theory suggests that SOEs are inefficient, since SOEs are more likely to pursue excess employment for political reasons (Shleifer and Vishny, 1994). In Regression 3, SOE is negatively related to productivity, but insignificant, indicating the existence of inefficiency in SOEs. The highly educated employee is significantly connected to enhanced productivity, as expected.

The inefficiency and low productivity in SOEs are argued to be the result of ownership structure; that is the absence of an ultimate owner $(\mathrm{Hu}, 2000)$. The government agents are the representative of the state assets but not the residual claimants. They have no incentive to monitor the management of enterprise. So the managers of the company seek to maximize their own interest, such as perking, rent-seeking, or on-the-job consumption, at the expense of the company (Shleifer and Vishny, 1994).

\section{Conclusion}

The empirical study here suggests that SOEs perform well in the Chinese property market. Inconsistent with the theory, no evidence is found that a state-owned property company is less efficient than a privately-owned property company. SOEs are larger in size, more profitable, attract more highly educated people, and pay senior managers higher salaries. Political factors affect the performance of SOEs. SOEs enjoy the government preferential treatment in terms of obtaining land at no or lower cost, access to cheaper financing, and taxation. SOEs also employ more people, maybe for political purposes, which impacts productivity.

Though China's property market is dominated by SOEs, it is not monopolized by them, as evidenced by the large number of POEs in the property industry. These POEs 
have been growing faster, actively participating in property development activities, and contributing greatly to China's property market. Compared with SOEs, POEs are still in a less competitive position. Given the short history of a private economy in China, it takes time for POEs to grow stronger and build up competence in the market.

The aims of the split share structure reform in the Chinese stock markets are to enhance the corporate governance mechanism and protect investor interest. When the reform is completed, foreign investors can undertake takeover, acquisition, or mergers with Chinese listed companies. This opens up opportunities for investors to invest in the Chinese real estate market. This research has a great implication for the international investors who wish to invest in the indirect real estate market in China.

\section{Endnotes}

1. A-shares are held by Chinese domestic individuals; B-shares were available exclusively to foreign investors until 2000 .

2. In accordance with the Circular on Promulgating the Administrative Measures on the Split Share Structure Reform of Listed Companies, issued by CSRC in September, 2005: (1) the non-tradable shares shall not be traded or transferred within 12 months from the date of implementation of the reform plan; (2) a former non-tradable shareholder who holds more than $5 \%$ of the total shares of a listed company, upon expiry of the lock-up period as stated in Article 27.1 of the Measures, may sell their shares, with a maximum of 5\% of the total shares of the listed company within 12 months via the trading system of the stock exchanges, and not more than $10 \%$ within 24 months

3. SOE refers here to the one that the state is the largest shareholder of the company (may not necessarily own over $50 \%$ ). This definition of state ownership has been used in previous China studies (e.g., Wei and Varela, 2003; and Bai, Liu, Lu, Frank, and Zhang, 2004).

4. Tobin's Q ratio: market value of liabilities is divided by the minimum cost of replacing the assets that represent these liabilities.

5. $S R_{t}=\frac{\text { Price }_{t}-\text { Price }_{t-1}}{\text { Price }_{t-1}}$.

\section{References}

Bai, C., Q. Liu, J.S. Lu, M. Frank, and J. Zhang. Corporate Governance and Market Valuation in China. Journal of Comparative Economics, 2004, 32, 599-616.

Bebchuk, L.A. A Rent-protection Theory of Corporate Ownership and Control. NBER working paper, No. 7203, 1999.

Chen, G.M., B.S. Lee, and O. Rui. Foreign Ownership Restrictions and Market Segmentation in China's Stock Markets. Journal of Financial Research, 2001, 24, 133-55.

Chui, A. and C. Kwok. Cross-autocorrelation between A-share and B-share in the China's Stock Market. Journal of Financial Research, 1998, 21, 333-53.

Hart, O. Firms, Contract and Financial Structure. Oxford: Oxford University Press, 1995.

Hu, R.R. Class Action: Practice in China. The Fourth Meeting of the Asian Roundtable, Mumbai, India, 2002.

Jones Lang LaSalle. Foreign Real Estate Investment Surges in Mainland China. 2007a, www. Jll.com. 
China 30. 2007b, www.Jll.com.

Ke, Q.L. and D. Isaac. Ownership Structure and Corporate Performance: Empirical Evidence of China's Listed Property Companies. Journal of Financial Management of Property and Construction, 2007, 12:1, 3-10.

La Porta, R., F. Lopez-de-Silanes, and A. Shleifer. Corporate Ownership Around the World. Journal of Finance, 1999, 54, 1115-55.

Lipton, D. and J. Sachs. Creating a Market Economy in Eastern Europe: The Case of Poland. Brookings Papers on Economic Activity, 1990, 1, 75-147.

Ma, S. Shareholding System Reform: the Chinese Way of Privatization. Communist Economies \& Economic Transformation, 1995, 7, 159-74.

Megginson, W.L. and J.M. Netter. From State to Market: A Survey of Empirical Studies of Privatisation. Journal of Economic Literature, 2001, 39:2, 321-89.

Nellis, J. Privatization in Africa: What Has Happened? What Is to Be Done? Centre for Global Development, Working paper, 2003.

Newell, G., K.W. Chau, and S.K. Wong. The Level of Direct Property in Hong Kong Property Company Performance. Journal of Property Investment and Finance, 2004, 22:6, 2512-532.

Newell, G., K.W. Chau, S.K. Wong, and K. McKinnell. Dynamics of the Direct and Indirect Real Estate Markets in China. Journal of Real Estate Portfolio Management, 2005, 11:3, 263 79.

Perotti, E. A Taxonomy of Post-socialist Financial Systems: Decentralized Enforcement and the Creation of Inside Money. Economics of Transition, 1994, 2:1, 71-81.

Perotti, E. State Ownership: A Residual Role? Global Corporate Governance Forum, discussion paper, No. 2, 2003, Washington, D.C.: The World Bank, available at: http://www.gcgf.org.

Shleifer, A. State versus Private Ownership. Journal of Economics Perspectives, 1998, 12:4, 133-150.

Shleifer, A. and R. Vishny. Large Shareholders and Corporate Control. Journal of Financial Economics, 1986, 5, 309-27.

—. Corruption. Quarterly Journal of Economics, 1993, 108:3, 599-617.

—. Politicians and Firms. Quarterly Journal of Economics, 1994, 109:4, 995-1025.

Sjoo, B. and J. Zhang. Market Segmentation and Information Diffusion in China's Stock Markets. Journal of Multinational Financial Management, 2000, 10:3/4, 421-38.

Wei, Z. and O. Varela. State Equity Ownership and Firm Market Performance: Evidence from China's Newly Privatized Firms. Global Finance Journal, 2003, 14, 65-82.

World Bank. Bureaucrats in Business. London, OUP, 1995.

Wang, Y. and X. Xu. Ownership Structure, Corporate Governance and Firm's Performance: The Case of Chinese Stock Companies. Washington, D.C.: The World Bank, 1997.

The author is grateful to the anonymous referees for the extensive detailed comments and suggestions, which substantially improved the quality of the paper. 
Copyright of Journal of Real Estate Literature is the property of American Real Estate Society and its content may not be copied or emailed to multiple sites or posted to a listserv without the copyright holder's express written permission. However, users may print, download, or email articles for individual use. 